\title{
EDITORIAL
}

cell biology

\section{CNRS evolution sparks revolution}

\section{At a time when change is necessary, French researchers are on the barricades resisting efforts to reform CNRS, the country's well respected basic research agency.}

Being a minister is not an easy task in France, a country famous for its propensity to be put on hold by protests against any change to the social, transport or health systems. When Valerie Pécresse was appointed minister for higher education and research in 2007, she must have been well aware that her plans for university and research reforms were unlikely to be readily accepted.

Soon after taking office, Pécresse granted state-run universities greater powers to steer their research strategies, manage their budgets and hire researchers on flexible salaries. These measures favour a competitive atmosphere more typical of American and British universities, and predictably encountered objections, in particular from students. Nevertheless, Pécresse cemented the programme into law after a few minor concessions, and now it is generally viewed as a positive development. Alongside increased university funding, the National Agency for Research (ANR) will receive just under one billion euros annually. This will be allocated across all research institutions as grants of 200,000-500,000 euros for four-year research projects, subject to evaluation by external experts.

The minister next set her sights on the CNRS, a bastion of French publicly funded research. This has had tempers flaring across the country in the last few weeks but it should have come as no surprise. Indeed, as far back as last autumn, the CNRS scientific council had voiced concerns that the government was about to implement drastic changes that could result in the disappearance of the CNRS altogether.

At present, a laboratory may be attached to several of the numerous sections that comprise the CNRS, an organizational structure in which research strategy is hard to manage. In the spring, Pécresse and the CNRS director, physicist Catherine Bréchignac, proposed to rationalize the forty sections of the CNRS into six institutes: mathematics, physics, chemistry, engineering, humanities and social sciences, and ecology and biodiversity. Directors of these institutes were to be appointed by the government.

What was to be the fate of biomedical sciences? No one knew exactly but fears were growing that the CNRS biology departments would be merged with INSERM, an equivalent of the NIH. Indeed, some believed that the creation of institutes was the first step in a plan to absorb the CNRS into the newly empowered universities.

Objections escalated, fuelled by the vagueness of the proposals. First, would universities be able to handle their new freedom in a manner favouring productive research? CNRS researchers are regarded as being successful and the view of those opposed to the reforms is "why break the one thing that works?" Second, if research, both at university and within the CNRS, becomes funded mainly by short-term ANR grants, would high-risk long-term projects remain appealing to scientists? CNRS employees, who have the financial security of civil servants, are more likely to undertake these projects, an advantage often regarded as key to the success of CNRS. Third, ANR is run by government appointees and may follow a particular political agenda rather than fund the best science. Similarly, appointing governmentnominated directors at CNRS may lead to an undue influence of politics on research. Fourth, with its emphasis on biomedical science, a takeover of biology by INSERM would surely be detrimental to basic research. Finally, thematically constrained institutes might impair cross-disciplinary collaboration. Remarkably, the creation of these institutes was actually meant to be Pécresse and Brechignac's solution to the present communication problems across the multitude of CNRS sections and departments.

Not all of these concerns are well founded. For example, ANR uses an international evaluation process that is likely to be more independent than current CNRS evaluation practices. Pécresse probably expected many of these objections when she proposed the changes. Indeed, one is inclined to muse that she may have been deliberately vague on some aspects of the reform to rattle CNRS scientists so that they would voice what really matters for their research. To further stir things up, she announced her plan in Le Monde in May 2008, ahead of the CNRS board meeting.

Save Research, a movement that helped prevent drastic research budget cuts in March 2003 (see Nature Cell Biology May 2004 Editorial) took to the streets again. Some argue that the ranks of Save Research are populated by researchers whose main motivation is to preserve their protected status, rather than internationally competitive scientists. So it was a coup de grace when Claire Lemercier, a successful CNRS historian who had just received one of the council medals, rallied more than 400 CNRS medallists to sign a declaration criticising the reform. The protests culminated in 2000 scientists blocking the CNRS board meeting in June this year.

Undeterred, the minister rescheduled the board meeting for July 1. The creation of institutes was adopted but eight were formed instead of the six initially planned, to include life and computer sciences. Other notable concessions were that CNRS, and not the government, will appoint institute directors, and the dropping of a privileged status planned for a subset of the institutes. Also, to promote a crossdisciplinary environment, the institutes will be allowed to grant funding to laboratories outside their remits. At the end of the day, the ministry has achieved its main goal, to create institutes, echoing what happened with last year's university reform.

President Nicolas Sarkozy's declared political agenda is to make science in France more attractive both to French scientists currently working abroad and to foreign researchers. Protesters claim that foreign researchers move to France for the security that positions abroad do not offer. However, given the relatively modest salaries (around 3,000 euros brutto per month for a starting principal investigator), one wonders whether it is actually the French way of life that is more attractive to them.

As the curtains are drawn on the political stage for summer, CNRS biomedical scientists will have to wait until autumn for concrete news about their fate. Let's hope that this time they will get involved from the start to shape the changes needed to reinvigorate French research.

Further reading: http://www.connotea.org/user/ncb/tag/CNRSreforms 